\title{
Influence of the host diet on the performance of Doryctobracon areolatus (Hymenoptera: Braconidae)
}

\author{
S. Ongaratto ${ }^{a, b *}$ (D) K. J. Pinto c (D), R. Mânica-Berto ${ }^{d}$ (D) S. D. Nörnberg' (D), R. S. Gonçalves ${ }^{d}$ (D), \\ M. S. Garcia ${ }^{a}$ (D) and D. E. Nava ${ }^{\text {(D) }}$
}

aPrograma de Pós-graduação em Fitossanidade, Departamento de Fitossanidade, Universidade Federal de Pelotas - UFPel, Campus Universitário, s/n, CEP 96900-010, Capão do Leão, RS, Brasil


Estadual Paulista - UNESP, Av. Universitária, 3780, Altos do Paraíso, CEP 18610-034, Botucatu, SP, Brasil

'Programa de Pós-graduação em Entomologia, Departamento de Ecologia, Zoologia e Genética, Instituto de Biologia, Universidade Federal de Pelotas - UFPel, Campus Universitário, s/n, CEP 96900-010, Capão do Leão, RS, Brasil

${ }^{\mathrm{d}}$ Laboratório de Entomologia, Embrapa Clima Temperado, Rodovia BR-392, Km 78, $9^{\circ}$ Distrito, Monte Bonito, CEP 96010-970, Pelotas, RS, Brasil

*e-mail: sabrina.ongaratto@hotmail.com

Received: December 20, 2018 - Accepted: May 30, 2019 - Distributed: November 30, 2020

(With 2 figures)

\begin{abstract}
Fitness in parasitoids is generally influenced by host quality. We evaluated the development parameters of Doryctobracon areolatus (Hymenoptera: Braconidae) parasitoid on Anastrepha fraterculus (Diptera: Tephritidae) larvae, reared in artificial diets with different protein sources. Larvae of $A$. fraterculus were reared in the diets based on 1)raw wheat germ (control); 2) whole rice flour; 3) corn flour; and, 4) whole wheat flour + soybean meal. The larvae were used for the development of $D$. areolatus, to evaluate the number of offspring/female, emergence rate, sex ratio, egg-adult period, adult weight posterior tibia length and longevity. Larvae of $A$. fraterculus reared in the diets based on wheat germ and corn flour obtained a greater number of offspring, with shorter duration of egg-adult period for males and females. In diets with rice flour and corn flour, A. fraterculus larvae generated adults of $D$. areolatus with greater weight, longer tibia length and higher sex ratio, whereas larvae reared in wheat flour + soybean meal diet had a lower sex ratio. The diets based on rice flour and corn are the most appropriate for multiplication of the parasitoid.
\end{abstract}

Keywords: biological control, artificial diets, mass rearing, parasitoid, biological parameters.

\section{Influência da dieta do hospedeiro na performance de Doryctobracon areolatus (Hymenoptera: Braconidae)}

\section{Resumo}

O custo adaptativo de parasitoides é geralmente influenciado pela qualidade do hospedeiro. Nós avaliamos parâmetros de desenvolvimento do parasitoide Doryctobracon areolatus (Hymenoptera: Braconidae) em larvas de Anastrepha fraterculus (Diptera: Tephritidae) criadas em dieta artificial com diferentes fontes proteicas. Larvas de A. fraterculus foram criadas em dietas a base de: 1) germe de trigo cru (testemunha); 2) farinha de arroz integral; 3) farinha de milho; e, 4) farinha de trigo integral + farelo de soja. As larvas foram usadas para o desenvolvimento de D. areolatus para avaliar o número de descendentes/fêmea, taxa de emergência, razão sexual, duração do período ovo-adulto, peso de adultos, comprimento da tíbia posterior e longevidade. Larvas de $A$. fraterculus criadas nas dietas a base de germe de trigo e farinha de milho, permitiram obter um maior número de descendentes do parasitoide, com menor duração do período de desenvolvimento ovo-adulto, para ambos os sexos. Nas dietas com farinha de arroz e farinha de milho, larvas de $A$. fraterculus geraram adultos de $D$. areolatus com maior peso e tamanho de tíbia de machos e fêmeas e uma maior quantidade de fêmeas. A dieta contendo farinha de trigo + farelo de soja afetou a geração de descendentes, causando uma menor razão sexual. As dietas a base de farinha de arroz e milho são as mais adequadas para a multiplicação do parasitoide.

Palavras-chave: controle biológico, dietas artificiais, criação massal, parasitoide, parâmetros biológicos. 


\section{Introduction}

Fruit flies (Diptera: Tephritidae) are one of the major problems for fruit-culture worldwide (Aluja and Mangan, 2008; Dias et al., 2018). In Brazil, the South American fruit fly Anastrepha fraterculus (Wiedemann, 1830) is considered a major pest to several fruits (Zucchi, 2008; Nunes et al., 2012). One potential parasitoid for the biological control of this species is Doryctobracon areolatus (Szépligeti, 1911) (Hymenoptera: Braconidae), one of the most frequent and abundant species in southern and southeastern states of Brazil (Garcia and Ricalde, 2012; Nunes et al., 2012; Paranhos et al., 2019).

Mass rearing of tephritid flies on an artificial diet is a critical point for the application of area-wide management programs and also provides the necessary substrate on which parasitoids should be used for biological control programs (Montoya et al., 2000; Zamek et al., 2012). Tephritid artificial diets, as many other insect diets, are usually mixtures of several ingredients that provide nutrients such as proteins, lipids, carbohydrates, vitamins and minerals, together with preservatives, $\mathrm{pH}$ modifiers, bulking agents, gelling agents and water (Cohen, 2004).

For a good performance of this insect's mass association, a diet that contains essential nutrients and easy assimilation by the larvae is extremely important, once it is responsible for its development, growth and reproduction in adult phase (Tsisipis, 1989; Rivera Ciprian et al., 2007). Thus, the nutritional quality of the diet is closely related to the quality of the nutrients, like the protein source, since protein is key nutrient during the larval phase (Nash and Chapman, 2014). Its deficiency leads to a lower adult emergence rate and a smaller insect size, among other effects (Kaspi et al., 2002), which may influence the multiplication of the parasitoid, since the size and quality of the larvae is associated with the success of parasitism and the emergence of females (Van Nieuwenhove and Ovruski, 2011). Moreover, their fitness is strongly influenced by host traits, like the quantity and quality of the host's nutrient resources (Godfray, 1994).

For A. fraterculus larval diets, many fruit flies rearing laboratories use raw wheat germ as a protein source, following the artificial diet proposed by Salles (1992). However, in most cases, raw wheat germ is imported. Thus, the use of local ingredients may guarantee the supply and generally a reduction of the production costs. However, any change in the diet quality during the immature development can have a significant effect on their biological characteristics (Nestel et al., 2016). Also, it can affect the number of parasitoid fitness components (Otto and Mackauer, 1998; Jervis et al., 2008), and could significantly influence parasitoid population dynamics (Cicero et al., 2011). Therefore, this study aimed to evaluate the biological parameters of $D$. areolatus parasitoid in $A$. fraterculus larvae reared in artificial diets with different protein sources.

\section{Material and Methods}

The experiments were performed in the Laboratory of Embrapa Clima Temperado (Pelotas, Rio Grande do Sul, Brazil) under standard conditions $\left(25 \pm 1{ }^{\circ} \mathrm{C}, 70 \pm 20 \%\right.$ $\mathrm{RH}$, and photophase of $12 \mathrm{~h}$ ).

\subsection{Maintenance rearing}

The maintenance rearing of Anastrepha fraterculus and Doryctobracon areolatus was performed using the methodologies proposed by Nunes et al. (2013) and Gonçalves (2016).

\subsection{Diets preparation}

Larvae of $A$. fraterculus were reared for six generations in artificial diets with four different ingredients: raw wheat germ $\left(\right.$ Walmon $\left.{ }^{\circledR}\right)$ (Diet 1), whole rice flour $\left(\right.$ Volkman $\left.^{\circledR}\right)$ (Diet 2), corn flour (Tordilho $\left.{ }^{\circledR}\right)$ (Diet 3 ) and a mixture of whole wheat flour $\left(\right.$ Panfácil $\left.^{\circledR}\right)+$ soybean meal (Walmon ${ }^{\circledR}$ ) (Diet 4). The amount of each ingredient was calculated according to the nutritional balance between proteins and carbohydrates (values given on package label), based on the raw wheat germ to ensure approximate quantities of macronutrients in the four diets, as well as the same total amount of other solid ingredients (Table 1).

Solid ingredients were placed in a blender to prepare the artificial diet, among them: refined sugar, yeast

Table 1. Ingredients used for the preparation of artificial diets for larval development of Anastrepha fraterculus. Composition for the preparation of 1.5 liters of artificial diet.

\begin{tabular}{|c|c|c|c|c|}
\hline \multirow[b]{2}{*}{ Ingredient } & \multicolumn{4}{|c|}{ Amount } \\
\hline & $\begin{array}{c}\text { Raw wheat } \\
\text { germ }\end{array}$ & $\begin{array}{c}\text { Whole rice } \\
\text { flour }\end{array}$ & Corn flour & $\begin{array}{l}\text { Whole wheat flour } \\
\text { + Soybean meal }\end{array}$ \\
\hline Yeast (g) & 90 & 130 & 130 & 100 \\
\hline Refined sugar (g) & 90 & 30 & 40 & 40 \\
\hline Agar (g) & 4.5 & 4.5 & 4.5 & 4.5 \\
\hline Sodium benzoate $(\mathrm{g})$ & 1.5 & 1.5 & 1.5 & 1.5 \\
\hline Nipagin (methylparahydroxybenzoate) (mL) & 12 & 12 & 12 & 12 \\
\hline Hydrochloric acid $(37 \%)(\mathrm{mL})$ & 10 & 10 & 10 & 10 \\
\hline Distilled water (mL) & 1000 & 1000 & 1000 & 1000 \\
\hline Raw Wheat Germ (g) & 90 & - & - & - \\
\hline Whole rice flour $(\mathrm{g})$ & - & 110 & - & - \\
\hline Corn flour (g) & - & - & 100 & - \\
\hline Whole wheat flour + Soybean meal $(\mathrm{g})$ & - & - & - & $100+30$ \\
\hline
\end{tabular}


Brewcell $^{\mathrm{TM}}$ (Biorigin), protein source corresponding to each treatment and sodium benzoate $\left(\right.$ Synth $\left.^{\circledR}\right)(1.5 \mathrm{~g})$, with $1000 \mathrm{~mL}$ of distilled water, $12 \mathrm{~mL}$ of Nipagin ${ }^{\mathrm{TM}}$ (methylparahydroxybenzoate) $\left(\right.$ Synth $\left.^{\circledR}\right)$, diluted at $10 \%$ in ethyl ethanol and $10 \mathrm{~mL}$ of concentrated hydrochloric acid at $37 \%\left(\operatorname{Vetec}^{\circledR}\right)$. Then, the ingredients were homogenized for $30 \mathrm{sec}$. Bacteriological agar $\left(\operatorname{Vetec}^{\circledR}\right)$ (4.5 g) was dissolved in $200 \mathrm{~mL}$ of distilled water, placed on fire and homogenized constantly until boiling. The mixture was added to the other ingredients in a blender and stirred for 2 min until final homogenization (Salles, 1992).

\subsection{Bioassay}

We used 20 couples of 24-hour-old D. areolatus, emerged from larvae of $A$. fraterculus reared in artificial diets with different protein sources, corresponding to each treatment. The couples were individualized in cages of plastic cups $(300 \mathrm{~mL})$ covered with voile fabric. A droplet of pure honey was used as food on $1 \mathrm{~cm}^{2}$ of Parafilm ${ }^{\circledR}$. Water was also provided by capillarity in glass tubes $(5 \mathrm{~mL})$ through cotton wool rolls.

Thirty $2^{\text {nd }}$ instar larvae of $A$. fraterculus were offered to each $D$. areolatus female, one day after couples formation and for 12 days. The larvae were transferred to parasitism units made of acrylic plates $(1.7 \mathrm{~cm}$ diameter $\times 0.1 \mathrm{~cm}$ high $)$ containing guava pulp, water and agar (substrate for the larvae), wrapped with voile fabric and disposed under the cages base to allow parasitism. For the control, a parasitism unit was prepared daily, similarly to the previous one and kept under the same conditions; however, it was not offered to females.

After 24-hour exposure, the larvae were transferred with a brush to acrylic jars $(4 \mathrm{~cm} \times 4.5 \mathrm{~cm}$ high) containing $20 \mathrm{~mL}$ artificial diet (Salles, 1992; Nunes et al., 2013), the same that the larvae began to develop. Then, the larvae were separated from the artificial diet by washing in running water with a sieve for retention and transferred to acrylic vials $(2.5 \mathrm{~cm}$ diameter $\times 4.5 \mathrm{~cm}$ high $)$ containing a thin layer of vermiculite to absorb moisture. Puparia remained in the bottles, in rooms with controlled conditions until the emergence. If emergence did not occur, they were dissected to verify the presence of parasitoids and/or flies.

The biological parameters evaluated were the number of offspring/female, emergence rate, sex ratio, egg-to-adult period, adult weight, posterior tibia length and longevity of males and females. The number of offspring (NO) was obtained by the equation: $\mathrm{NO}=$ number of parasitoids emerged + number of parasitoids not emerged. To determine the emergence rate, we used the following Equation 1:

$$
E \%=\left[\begin{array}{l}
(\text { number of parasitoids emerged } x \text { 100)/ } \\
\text { total number of offspring }
\end{array}\right]
$$

The sex ratio was calculated through according to Silveira Neto et al. (1976).

Evaluations were carried out daily, in order to determine the date of parasitoid emergence and register the duration of egg-to-adult period. At emergence, the vials were inspected and 50 adults of each sex and of each treatment were separated and weighed after $48 \mathrm{~h}$. We used a precision balance (Shimadzu, AUY 220) to determine the body weight. The tibia size of the parasitoid was measured using a stereoscope microscope Zeiss with graduated eyepieces and $4 \mathrm{x}$ magnifying. To determine longevity, the mortality of the 20 couples formed was recorded daily.

\subsection{Statistical analysis}

The experiment was conducted in a completely randomized design, in unifactorial scheme with 20 repetitions. The treatment comprised $A$. fraterculus larvae reared in four diets with different protein sources. Each experimental unit was formed by one couple of $D$. areolatus.

The data was analyzed for normality by the Shapiro Wilk test. Homoscedasticity was tested with Hartley test, and residual independence with graphical analysis. Then, the data were subjected to a variance analysis using $\mathrm{F}$ test $(p \leq 0.05)$. In case of statistical significance, Waller-Duncan $(p \leq 0.05)$ test was used to evaluate the effects of protein sources. The comparison with the control treatment (raw wheat germ) was performed with Dunnett test $(p \leq 0.05)$. Parasitoid longevity was analyzed by the construction of survival curves using the Kaplan-Meier estimator, which were compared with the log-rank test (R Development Core Team, 2015).

\section{Results}

We found statistical significance for the offspring number $(\mathrm{F}=6.35 ; \mathrm{df}=3 ; p=0.0011)$, sex ratio $(\mathrm{F}=3.95$; df $=3 ; p=0.0140)$ and egg-to-adult period for males $(\mathrm{F}=69.67 ; \mathrm{df}=3 ; p<0.0001)$ and females $(\mathrm{F}=67.69$; $\mathrm{df}=3 ; p<0.0001$ ) for treatment factor tested (larvae origin). However, the emergence rate did not show the effect of protein source $(\mathrm{F}=1.05 ; \mathrm{df}=3 ; p=0.3779)$ (Table 2$)$.

The daily parasitism rate showed oscillations at all diets (Figure 1). For the offspring parameter, the diet containing corn flour provided the higher number of parasitoid $(42.14 \pm 0.56)$, together the diet with wheat germ $(65.73 \pm 0.89)$. The emergence rate remained high, above $80 \%$, for all treatments. Diets containing rice and corn flour, as well as the control, provided the appropriate conditions to ensure that emergence of parasitic insects was close to ratio of one female for one male, that is close to 0.50 . In relation to duration of the the egg-adult period, for both males and females, the lowest cycle was identified for the offspring generated from the diet containing corn flour $(20.00 \pm 0.01$ and $22.00 \pm 0.01$, respectively) (Table 2).

For adult weight in males $(\mathrm{F}=31.05 ; \mathrm{df}=3 ; p<0.0001)$, females $(\mathrm{F}=11.55 ; \mathrm{df}=3 ; p<0.0001)$ and posterior tibia length in females $(\mathrm{F}=6.21 ; \mathrm{df}=3 ; p=0.0005)$ showed significance for the effect of larvae origin, once the parasitoids coming from the diets containing rice and corn presented the highest values for these parameters, besides the control treatment . However, tibia length of the last pair of legs in males of $D$. areolatus $(\mathrm{F}=1.06$; 
$\mathrm{df}=3 ; p=0.3652$ ) showed no statistical significance for the treatment factor tested (Table 3 ).

The result of the log-rank test showed that longevity of males $\left(\chi^{2}=23.3\right.$; df $\left.=3 ; p=0.00003\right)$ and females $\left(\chi^{2}=7.5 ; \mathrm{df}=3 ; p=0.04\right)$ of $D$. areolatus was significantly affected by different protein sources. For $D$. areolatus males reared in larvae of $A$. fraterculus from artificial diets containing wheat germ, rice flour, corn flour and wheat

Table 2. Number of offspring per female, emergence rate (\%), sex ratio and duration of egg-to-adult period (days) of males and females of Doryctobracon areolatus reared in larvae of Anastrepha fraterculus from artificial diets with different protein sources. Temperature $25 \pm 1{ }^{\circ} \mathrm{C}, 70 \pm 20 \% \mathrm{RH}$ and photophase of $12 \mathrm{~h}$.

\begin{tabular}{|c|c|c|c|c|c|}
\hline \multirow{2}{*}{ Protein source } & \multirow{2}{*}{$\begin{array}{c}\text { Number of } \\
\text { offspring/female }\end{array}$} & \multirow{2}{*}{$\begin{array}{c}\text { Emergence rate } \\
(\%)\end{array}$} & \multirow{2}{*}{ Sex ratio } & \multicolumn{2}{|c|}{ Duration egg-adult period (days) } \\
\hline & & & & Males & Females \\
\hline $\begin{array}{l}\text { Raw wheat } \\
\text { germ (control) }\end{array}$ & $65.73 \pm 0.89$ & $97.47 \pm 0.81 \quad \mathrm{NS}$ & $0.56 \pm 0.03$ & $20.00 \pm 0.01$ & $22.00 \pm 0.01$ \\
\hline Whole rice flour & $21.23 \pm 0.39 \mathrm{~b}^{1 / *}$ & $98.56 \pm 0.71$ & $0.50 \pm 0.08 a^{\mathrm{ns}}$ & $20.50 \pm 0.11 \mathrm{~b} *$ & $23.00 \pm 0.01 \mathrm{a}^{*}$ \\
\hline Corn four & $42.14 \pm 0.56 \mathrm{a}^{\mathrm{ns}}$ & $90.46 \pm 8.24$ & $0.48 \pm 0.06 \mathrm{a}^{\mathrm{ns}}$ & $20.00 \pm 0.01 \mathrm{c}^{\mathrm{ns}}$ & $22.00 \pm 0.01 b^{n s}$ \\
\hline $\begin{array}{l}\text { Whole wheat } \\
\text { flour }+ \text { soybean } \\
\text { meal }\end{array}$ & $26.43 \pm 0.69 \mathrm{~b} *$ & $83.09 \pm 11.21$ & $0.26 \pm 0.08 \mathrm{~b} *$ & $21.00 \pm 0.01 \mathrm{a}^{*}$ & $23.00 \pm 0.01 \mathrm{a}^{*}$ \\
\hline
\end{tabular}

${ }^{1 /}$ Means $( \pm$ SE) followed by the same letter in the column do not differ by the Waller-Duncan test $(p \leq 0.05)$ comparing the protein sources; *significant and ns not significant, respectively, in relation to the control (wheat germ) by the Dunnett test $(p \leq 0.05)$;

${ }^{\mathrm{NS}}$ not significant by the $\mathrm{F}$ test $(p \leq 0.05)$ of the analysis of variance.

Table 3. Adult weight $(\mathrm{mg})$ and posterior tibia length $(\mathrm{mm})$ of males and females of Doryctobracon areolatus reared in larvae of Anastrepha fraterculus in artificial diets with different protein sources. Temperature $25 \pm 1{ }^{\circ} \mathrm{C}, 70 \pm 20 \% \mathrm{RH}$ and photophase of $12 \mathrm{~h}$.

\begin{tabular}{|c|c|c|c|c|}
\hline \multirow{2}{*}{ Protein source } & \multicolumn{2}{|c|}{ Adult weight (mg) } & \multicolumn{2}{|c|}{ Posterior tibia length (mm) } \\
\hline & Males & Females & Males & Females \\
\hline $\begin{array}{l}\text { Raw wheat germ } \\
\text { (control) }\end{array}$ & $4.00 \pm 0.12$ & $5.28 \pm 0.14$ & $1.15 \pm 0.02 \mathrm{NS}$ & $1.27 \pm 0.02$ \\
\hline Whole rice flour & $3.76 \pm 0.14 \mathrm{a}^{\mathrm{ns}}$ & $4.66 \pm 0.13 \mathrm{a}^{*}$ & $1.14 \pm 0.02$ & $1.34 \pm 0.02 \mathrm{a}^{1 / *}$ \\
\hline Corn four & $3.77 \pm 0.11 \mathrm{a}^{\mathrm{ns}}$ & $4.79 \pm 0.11 \mathrm{a}^{*}$ & $1.18 \pm 0.02$ & $1.37 \pm 0.01 \mathrm{a} *$ \\
\hline $\begin{array}{l}\text { Whole wheat flour } \\
+ \text { soybean meal }\end{array}$ & $2.51 \pm 0.11 \mathrm{~b} *$ & $4.25 \pm 0.13 \mathrm{~b} *$ & $1.13 \pm 0.02$ & $1.28 \pm 0.02 \mathrm{~b}^{\mathrm{ns}}$ \\
\hline
\end{tabular}

${ }^{1 /}$ Means $( \pm$ SE) followed by the same letter in the column do not differ by the Waller-Duncan test $(p \leq 0.05)$ comparing the protein sources; *significant and ns not significant, respectively, in relation to the control (wheat germ) by the Dunnett test $(p \leq 0.05)$; ${ }^{\mathrm{NS}}$ not significant by the $\mathrm{F}$ test $(p \leq 0.05)$ of the analysis of variance.



Figure 1. Daily rate of offspring produced by females of Doryctobracon areolatus reared in larvae of Anastrepha fraterculus from artificial diets with different protein sources. Temperature $25 \pm 1{ }^{\circ} \mathrm{C}, 70 \pm 20 \% \mathrm{RH}$ and photophase of $12 \mathrm{~h}$. 

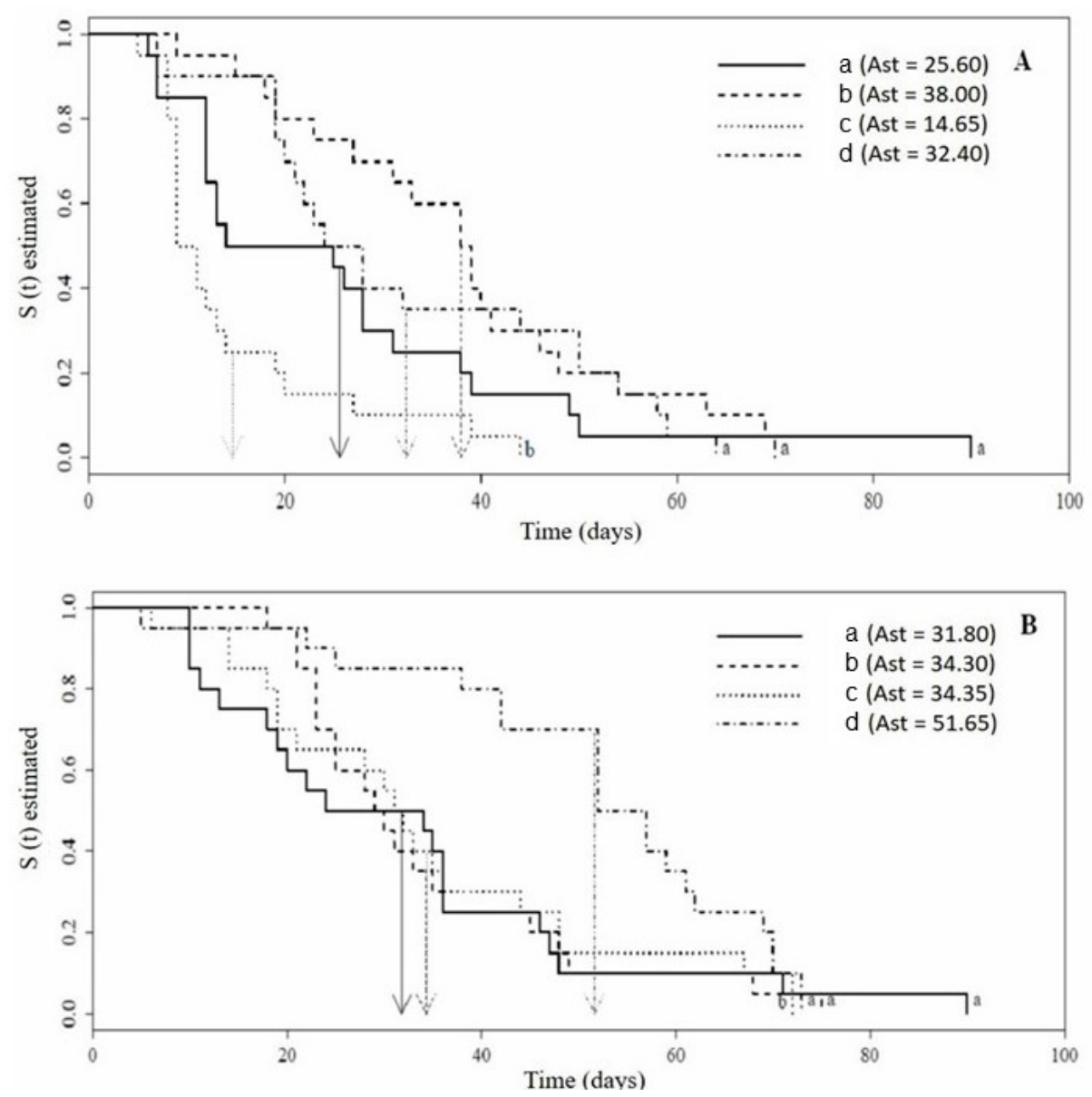

Figure 2. Survival curves of males (A) and females (B) of Doryctobracon areolatus reared in larvae of Anastrepha fraterculus from artificial diets with different protein sources $(a=$ raw wheat germ; $b=$ whole rice flour; $c=$ corn flour; and $d=$ whole wheat flour + soybean meal). Temperature $25 \pm 1{ }^{\circ} \mathrm{C}, 70 \pm 20 \% \mathrm{RH}$ and photophase of $12 \mathrm{~h}$. Curves followed by the same letters for each sex do not differ by the log-rank test. AST = average survival time.

flour + soybean meal, the average survival time (AST) was $25.60,38.00,14.65$, and 32.40 days, respectively. For females, the values found were $31.80,34.30$, 34.35, and 51.65 days for the same diets (Figure 2).

\section{Discussion}

The results of this study have shown that the food ingested by host influences the biological parameters of D. areolatus. In general, the diets based on corn flour and rice flour allowed a better performance of the parasitoid, both in pre-imaginal period and in adult life. Parasitoid fitness is known to be closely associated with quality of their host (Henry et al., 2005; Vinson, 2010). In this study, we tested the effect of host species fed with different sources of protein during the larval phase on parasitoid fitness parameters, such as development time, longevity, fecundity, sex ratio, emergence rate and size of offspring.

The decline in generated offspring that was observed in the diets based on rice flour and mixture of wheat flour + soybean meal was not recorded in the other diets. Cancino et al. (2002) observed that the oviposition of D. longicaudata intensifies from the 5 th day onward and extends for a period of 10-15 days. In practical terms, these results allow improving adult management in parasitism in a laboratory rearing, given that the costs for rearing maintenance with ingredients purchase and labor are high. Due to this fact, the parasitism period could be extended for the insects from diets based on corn and wheat.

The higher number in offspring generated with the use of diet containing corn and wheat (control) can be attributed to the host larvae quality as well as the allocation and efficiency utilization of essential nutrients (Jervis et al., 2008), provided by these protein sources. Another explanation for this behavior is $D$. areolatus reproductive plasticity regarding their key reproductive traits. When Cicero et al. (2011) compared the effects of different $A$. ludens diets on the fitness of several parasitoid species, D. longicaudata changed and adjusted reproductive investment index to host diet/quality. 
In this study, the number of females generated was approximately $50 \%$ of the offspring for most diets, except for whole wheat flour + soybean meal. This is important, since the sex ratio of $D$. areolatus is a limiting factor in mass rearing of parasitoids in biological control programs. In addition, to allow a higher population growth rate, the ratio should be biased towards females, because males do not contribute to pest mortality (Heimpel and Lundgren, 2000). The higher proportion of females can be influenced by the interaction of multiple factors, one of them is larval quality (Sagarra et al., 2001; Van Nieuwenhove and Ovruski, 2011), concerning the use of protein ingredients in the host food.

Adult size, development time, and survival are the three best-studied fitness correlates in parasitoids. These parameters vary in accordance with the host traits, such as size or instar parasitized, host species, nutritional status (e.g., diet) (Harvey, 2005).

The development time of egg-to-adult period for males was longer with the use of a diet containing wheat flour + soybean meal and rice flour, greatly differing from each other and the control (wheat germ). For females, rice flour diet did not significantly differ from the diet based on wheat flour + soybean meal; however, both differed from the control. The only diet in both situations that could replace wheat germ in this parameter is the one containing corn flour, which showed values equal to the control regarding the egg-to-adult period. The food source that fed the host might influence parameters of the adult parasitoid. In this sense, a faster development would result in a sexually mature and it would be possible to reproduce the offspring (Godfray, 1994), making it possible to rearing parasitoids in a shorter time and consequently decreasing the production costs.

Males of $D$. areolatus from $A$. fraterculus larvae reared in a diet containing rice and corn flour showed higher values for the body weight factor, and they did not differ from the control. Although, the diets provided greater weight gain to insects when comparing to all protein sources, for females, the diets significantly differed from the control. In general, higher body weight and longer size of tibia are related. Females of the parasitoid reared in $A$. fraterculus from artificial diets with protein source based on rice and corn flour demonstrated greater values for posterior tibia. These protein sources enabled a longer length of tibia when compared with wheat germ (control). However, the mixture of wheat four + soybean meal did not differ from wheat germ.

Overall, the parasitoids from the diet based on rice and corn flour presented greater tibia size, larger body weight and better results for most of the parameters evaluated. Independent of fecundity, there may be additional advantages to large body size. According to Lawrence et al. (1976), larger insects may be able to move over greater distances in search for hosts in field conditions, this is extremely desirable for biological control agents rearing or better able to reach hosts within infested substrates with their longer ovipositors (Sivinski et al., 2001).
Parasitoid survival is directly related to the host size; therefore, insects developed in larger hosts endure longer (Sagarra et al., 2001). According to Visser and Ellers (2008), this relationship is explained by greater availability of nutritional resources in larger hosts. This condition has been described for D. longicaudata (López et al., 2009); nevertheless, in this study, there was contradiction for diet with wheat flour + soybean meal, which presented higher average survival values for females and decreased sizes. Despite this fact, studies involving different food sources that enhance adult parasitoid survival in the field could improve the diets of parasitoids mass reared for augmentative releases and help direct natural enemy introduction and conservation (Sivinski et al., 2006).

The results obtained in this study have shown that rice and corn flour can replace wheat germ in diets to rearing the larvae of $A$. fraterculus and its parasitoid D. areolatus, serving as basis for programs involving the rearing of these species.

\section{Acknowledgements}

This research was carried out with support of the Coordenação de Aperfeiçoamento de Pessoal de Nível Superior - CAPES - Funding Code 001. We also thank Empresa Brasileira de Pesquisa Agropecuária - Embrapa for the financial support.

\section{References}

ALUJA, M. and MANGAN, R.L., 2008. Fruit fly (Diptera: Tephritidae) host status determination: critical conceptual, methodological, and regulatory considerations. Annual Review of Entomology, vol. 53, no. 1, pp. 473-502. http://dx.doi.org/10.1146/ annurev.ento.53.103106.093350. PMid:17877455.

CANCINO, J., VILLALOBOS, P. and DE LA TORRES, S., 2002. Changes in the rearing process to improve the quality of mass production of the fruit parasitoid Diachasmimorpha longicaudata (Ashmead) (Hymenoptera: Braconidae). In: N.V. LEPPLA, K.A. BLOEM and R.F. LUCK, eds. Proceeding of 7 th workshop of the global IOBC Working Group: quality control of mass reared arthropods. Italy: Rimmi, pp. 74-82.

CICERO, L., SIVINSKI, J., RULL, J. and ALUJA, M., 2011. Effect of larval host food substrate on egg load dynamics, egg size and adult female size in four species of braconid fruit fly (Diptera: Tephritidae) parasitoids. Journal of Insect Physiology, vol. 57, no. 11, pp. 1471-1479. http://dx.doi.org/10.1016/j. jinsphys.2011.07.014. PMid:21819991.

COHEN, A.C., 2004. Insect diets: science and technology. Florida: CRS Press, $324 \mathrm{p}$.

DIAS, N.P., ZOTTI, M.J., MONTOYA, P., CARVALHO, I.R. and NAVA, D.E., 2018. Fruit fly management research: a systematic review of monitoring and control tactics in the world. Crop Protection, vol. 112, pp. 187-200. http://dx.doi.org/10.1016/j. cropro.2018.05.019.

GARCIA, F.R.M. and RICALDE, M., 2012. Augmentative biological control using parasitoids for fruit fly management in Brazil. Insects, vol. 4, no. 1, pp. 55-70. http://dx.doi.org/10.3390/ insects4010055. PMid:26466795. 
GODFRAY, H.C.J., 1994. Parasitoids: behavioral and evolutionary ecology. Princeton: Princeton University Press, 488 p.

GONÇALVES, R.S., 2016. Bioecologia e competição interespecífica de parasitoides (Hymenoptera: Braconidae) de moscas-das-frutas (Diptera: Tephritidae). Pelotas: Universidade Federal de Pelotas, 183 p. Tese de Doutorado em Fitossanidade.

HARVEY, J.A., 2005. Factors affecting the evolution of development strategies in parasitoid wasps: the importance of functional constraints and incorporating complexity. Entomologia Experimentalis et Applicata, vol. 117, no. 1, pp. 1-13. http:// dx.doi.org/10.1111/j.1570-7458.2005.00348.x.

HEIMPEL, G.E. and LUNDGREN, J.G., 2000. Sex ratios of commercially reared biological control agents. Biological Control, vol. 19, no. 1, pp. 77-93. http://dx.doi.org/10.1006/bcon.2000.0849.

HENRY, L.M., GILLESPIE, D.R. and ROITBERG, B.D., 2005. Does mother really know best? Ovipositions preferences reproductive performance in the generalist parasitoid Aphidius ervi. Entomologia Experimentalis et Applicata, vol. 116, no. 3, pp. 167-174. http://dx.doi.org/10.1111/j.1570-7458.2005.00318.x.

JERVIS, M.A., ELLERS, J. and HARVEY, J.A., 2008. Resource acquisition, allocation and utilization in parasitoid reproductive strategies. Annual Review of Entomology, vol. 53, no. 1, pp. 361385. http://dx.doi.org/10.1146/annurev.ento.53.103106.093433. PMid:17877453.

KASPI, R., MOSSINSON, S., DREZNER, T., KAMENSKY, B. and YUVAL, B., 2002. Effects of larval diet on development rates and reproductive maturation of male and female Mediterranean fruit flies. Physiological Entomology, vol. 27, no. 1, pp. 29-38. http://dx.doi.org/10.1046/j.1365-3032.2001.00264.x.

LAWRENCE, P.O., BARANOWSKI, R.M. and GREANY, P.D., 1976. Effect of host age on development of Biosteres (= Opius) longicaudatus, a parasitoid of the Caribbean fruit fly, Anastrepha suspensa. The Florida Entomologist, vol. 59, no. 1, pp. 33-39. http://dx.doi.org/10.2307/3493166.

LÓPEZ, O.P., HÉNAUT, Y., CANCINO, J., LAMBIN, M., CRUZLÓPEZ, L. and ROJAS, J.C., 2009. Is host size an indicator of quality in the mass-reared parasitoid Diachasmimorpha longicaudata (Hymenoptera: braconidae)? The Florida Entomologist, vol. 92, no. 3, pp. 441-449. http://dx.doi.org/10.1653/024.092.0305.

MONTOYA, P., LIEDO, P., BENREY, B., CANCINO, J., BARRERA, J.F., SIVINSKI, J. and ALUJA, M., 2000. Biological control of Anastrepha spp. (Diptera: Tephritidae) in Mango Orchards through augmentative releases of Diachasmimorpha longicaudata (Ashmead) (Hymenoptera: Braconidae). Biological Control, vol. 18, no. 3, pp. 216-224. http://dx.doi.org/10.1006/ bcon.2000.0819.

NASH, W.J. and CHAPMAN, T., 2014. Effect of dietary components on larval life history characteristics in the Medfly (Ceratitis capitata: Diptera, Tephritidae). PLoS One, vol. 9, no. 1, pp. e86029. http://dx.doi.org/10.1371/journal.pone.0086029. PMid:24465851.

NESTEL, D., PAPADOPOULOS, N.T., PASCACIO-VILLAFÁN, C., RIGHINI, N., ALTÚZAR-MOLINA, A.R. and ALUJA, M., 2016. Resource allocation and compensation during development in holometabolous insects. Journal of Insect Physiology, vol. 95, pp. 78-88. http://dx.doi.org/10.1016/j.jinsphys.2016.09.010. PMid:27650504

NUNES, A.M., COSTA, K.Z., FAGGIONI, K.M., COSTA, M.L.Z., GONÇALVES, R.S., WALDER, J.M.M., GARCIA,
M.S. and NAVA, D.E., 2013. Dietas artificiais para a criação de larvas e adultos da mosca-das-frutas sul-americana. Pesquisa Agropecuária Brasileira, vol. 48, no. 10, pp. 1309-1314. http:// dx.doi.org/10.1590/S0100-204X2013001000001.

NUNES, A.M., MÜLLER, F.A., GONÇALVES, R.S., GARCIA, M.S., COSTA, V.A. and NAVA, D.E., 2012. Moscas frugívoras e seus parasitoides nos municípios de Pelotas e Capão do Leão, Rio Grande do Sul, Brasil. Ciência Rural, vol. 42, no. 1, pp. 6-12. http://dx.doi.org/10.1590/S0103-84782012000100002.

OTTO, M. and MACKAUER, M., 1998. The developmental strategy of an idiobiont ectoparasitoid, Dendrocerus carpenteri: influence of variations in host quality on offspring growth and fitness. Oecologia, vol. 117, no. 3, pp. 353-364. http://dx.doi. org/10.1007/s004420050668. PMid:28307914.

PARANHOS, B.J., NAVA, D.E. and MALAVASI, A., 2019. Biological control of fruit flies in Brazil. Pesquisa Agropecuária Brasileira, vol. 54, no. 0, pp. e26037. http://dx.doi.org/10.1590/ s1678-3921.pab2019.v54.26037.

R DEVELOPMENT CORE TEAM, 2015 [viewed 15 April 2019]. $R$ : a language and environment for statistical computing [online]. Vienna: R Foundation for Statistical Computing. Available from: http://www.Rproject.org/

RIVERA CIPRIAN, J.P., HERNÁNDEZ, E., TOLEDO, J., SALVADOR, M. and SILVA, R., 2007. Dieta texturizada con agar para el desarrollo larvario de tres especies de moscas de la fruta (Diptera: tephritidae). Folia Entomologica Mexicana, vol. 46 , no. 1 , pp. 37-52.

SAGARRA, L.A., VINCENT, C. and STEWART, R.K., 2001. Body size as an indicator of parasitoid quality in male and female Anagyrus kamali (Hymenoptera: encyrtidae). Bulletin of Entomological Research, vol. 91, no. 5, pp. 363-368. http:// dx.doi.org/10.1079/BER2001121. PMid:11583599.

SALLES, L.A.B., 1992. Metodologia de criação de Anastrepha fraterculus (Wiedemann, 1830) (Diptera: Tephritidae) em dieta artificial em laboratório. Anais da Sociedade Entomológica do Brasil, vol. 21, pp. 479-486.

SILVEIRA NETO, S., NAKANO, O., BARBIN, D. and VILLA NOVA, N.A., 1976. Manual de ecologia dos insetos. Piracicaba: Agronômica Ceres, 419 p.

SIVINSKI, J., ALUJA, M. and HOLLER, T., 2006. Food sources for adult Diachasmimorpha longicaudata, a parasitoid of tephritid fruit flies: effects on longevity and fecundity. Entomologia Experimentalis et Applicata, vol. 118, no. 3, pp. 193-202. http:// dx.doi.org/10.1111/j.1570-7458.2006.00379.x.

SIVINSKI, J., VULINEC, K. and ALUJA, M., 2001. Ovipositor length in a guild of parasitoids (Hymenoptera: Braconidae) attacking Anastrepha spp. fruit flies (Diptera: Tephritidae) in southern Mexico. Annals of the Entomological Society of America, vol. 94, no. 6, pp. 886-895. http://dx.doi.org/10.1603/00138746(2001)094[0886:OLIAGO]2.0.CO;2.

TSISIPIS, J.A., 1989. Nutrition. In: A.S. ROBINSON, ed. Fruit flies their biology, natural enemies and control. Amsterdam: Elsevier Press, pp. 103-119.

VAN NIEUWENHOVE, G.A. and OVRUSKI, S.M., 2011. Influence of Anastrepha fraterculus (Diptera: Tephritidae) larval instars on the production of Diachasmimorpha longicaudata (Hymenoptera: Braconidae) progeny and their sex ratio. The Florida Entomologist, vol. 94, no. 4, pp. 863-868. http://dx.doi. org/10.1653/024.094.0421. 
VINSON, S.B., 2010. Nutritional ecology of insect egg parasitoids. In: F.L. CÔNSOLI, J.R.P. PARRA and R.A. ZUCCHI, eds. Egg parasitoids in agroecosystems with emphasis on Trichogramma. London: Springer, pp. 25-55.

VISSER, B. and ELLERS, J., 2008. Lack of lipogenesis in parasitoids: a review of physiological mechanisms and evolutionary implications. Journal of Insect Physiology, vol. 54, no. 9, pp. 1315-1322. http://dx.doi.org/10.1016/j.jinsphys.2008.07.014. PMid:18706420.
ZAMEK, A.L., SPINNER, J.E., MICALLEF, J.L., GURR, G.M. and REYNOLDS, O.L., 2012. Parasitoids of Queensland fruit fly Bactrocera tryoni in Australia and prospects for improved biological control. Insects, vol. 3, no. 4, pp. 1056-1083. http:// dx.doi.org/10.3390/insects3041056. PMid:26466726.

ZUCCHI, R.A., 2008 [viewed 15 April 2019]. Fruit flies in Brazil: Anastrepha species their host plants and parasitoids [online]. Piracicaba: USP. Available from: http://www.lea.esalq. usp. br/anastrepha/ 